https://helda.helsinki.fi

\title{
Humanity Discourse and the Disciplining of the State
}

\author{
Soirila, Ukri
}

2018-09

Soirila, U 2018 , ' Humanity Discourse and the Disciplining of the State ' , Chinese Journal of International Law , vol. 17 , no. 3 , pp. 861-885 . https://doi.org/10.1093/chinesejil/jmy015

http://hdl.handle.net/10138/325013

https://doi.org/10.1093/chinesejil/jmy015

unspecified

acceptedVersion

Downloaded from Helda, University of Helsinki institutional repository.

This is an electronic reprint of the original article.

This reprint may differ from the original in pagination and typographic detail.

Please cite the original version. 


\title{
Humanity discourse and the disciplining of the state
}

\author{
Ukri Soirila*
}

\begin{abstract}
Since the end of Cold War, international legal discussion and practice has been increasingly permeated by what this article calls "humanity discourse". The article analyzes the discourse from a critical perspective. The main argument of the article is that the humanity discourse contributes to what Anne Orford has called the "battle for the state", and consequently to the neoliberal project which is now a hegemonic power in global law and policy. This argument is supported both by an analysis of humanity discourse in academic discussions and an analysis of how humanity language has been used in practice.
\end{abstract}

\section{Introduction}

1. Since the end of Cold War, there has been an increasing focus on the human in international legal discourse. This focus has manifested itself, to name just a few examples, in the final breakthrough of human rights language, the emergence of international criminal law, the concepts of human security and the responsibility to protect, and new developments within fields such as international investment law and humanitarian law. Within academia, these developments have been described as the "humanization" of international law, the replacement of sovereignty with humanity as the guiding principle of international law, ${ }^{2}$ or even as the establishment of a new global law of humanity ${ }^{3}$ or "humanity's law". ${ }^{4}$ Whatever we choose to call this development,

* Doctoral candidate, Faculty of Law, The Erik Castrén Institute of International Law and Human Rights, University of Helsinki. I wish to thank Anne Orford and Martti Koskenniemi for their helpful comments on the article. This revised version of the paper was submitted on 22 February 2018.

1 Theodor Meron, The Humanization of International Law (2006); Vassilis P Tzevelekos, Revisiting the Humanisation of International Law: Limits and Potential: Obligations Erga Omnes, Hierarchy of Rules and the Principle of Due Diligence as the Basis for Further Humanisation 6 Erasmus LR (2013), 62.

2 Anne Peters, Humanity as the A and $\Omega$ of Sovereignty, 20 European Journal of International Law (2009), 513.

3 Rafael Domingo, The New Global Law (2011). See also Antonio Augusto Cançado Trindade, International Law for Humankind (2010). 
however, it seems uncontested that there is an increasing circulation of humanity discourse in international law.

2. This article subjects the increasing circulation of humanity discourse to a critical analysis, so as to discover its potential blind spots, biases, and hidden pitfalls. In particular, the article raises concerns about the way the discourse may be linked to the current hegemony of neoliberalism which, I suggest, is inimical to the main tenets of the humanity discourse, namely the protection of human rights, the human security of the weak, and the empowerment of the oppressed.

3. The suggestion that the humanity discourse is linked to trade, markets, and neoliberalism might sound both counter-intuitive and banal, depending on how it is understood. On the one hand, it is true that much of the literature advocating for the humanization of international law is written in order to counter some of the destructive effects of global capitalism. Authors such as Rafael Domingo and Eyal Benvenisti have argued that a humanity-oriented rethinking of international law and statehood is required precisely to fight such contemporary phenomena as global capitalism. ${ }^{5}$ Looked at from this perspective, then, the humanity discourse seems to be almost entirely at odds with the neoliberal project.

4. On the other hand, linking humanity to neoliberalism, trade, and markets might seem banal, considering, for example, the endless debate on "trade and human rights". In an excellent coverage of the discussion, Andrew Lang has shown how human rights and trade regimes have been entangled together since the birth of the regimes in the aftermath of the Second World War. ${ }^{6}$ Lang writes against the common narrative according to which the regimes have stood in isolation and "have only recently been forced to confront one another, as a result of changes in the organization of the global economy, as well as the expansion of each regime's mandate and ambition". By contrast, he demonstrates convincingly that the regimes were born as mutually compatible parts of a system of embedded liberalism, and that there has "always been a range of deeply held and well-developed ideas about how international trade relates to the protection and promotion of human rights, and that the nature of this relationship has been a terrain of struggle and political contest for some

Ruti Teitel, Humanity's Law (2011).

5 Rafael Domingo (n 4) xiii, 61-65; Eyal Benvenisti, Sovereigns as Trustees of Humanity: On the Accountability of States to Foreign Stakeholders, 107 The American Journal of International Law (2013), 303.

6 Andrew Lang, World Trade Law after Neoliberalism: Reimagining the Global Economic Order (2013), Chapters 2-5. 
time". 7

5. According to Lang, there have been three key stages in the relations between the trade and human rights regimes. As already stated, in the first stage the two regimes were linked through the underlying idea of embedded liberalism. If the two seemed distinct, it was mostly because no interaction was needed between the two, as they served the same overall project in different fields. The system of embedded liberalism was challenged, then, in the second stage of Lang's description, by the development ideas of the 1960s and 1970s, which drew attention to the way the developed North was exploiting the developing South. During this period, a new understanding of human rights put development and economic and social rights at the center of the human rights discourse, and the links between under-development and trade were unearthed within economic discourse. Consequently, human rights language was increasingly used to challenge the liberal aspects of international trade. Crucially, however, there was no struggle between the two regimes per se; rather, political struggles between the North and the South were fought within both regimes simultaneously. In the third stage, in the 1980s and 1990s, neoliberalism emerged as the dominant position within trade discourse, linking free markets, free trade, and economic globalization into a single, mutually reinforcing economic project. Neoliberalism also penetrated the human rights regime, which split roughly into two camps: between those for whom economic liberalization, enabled by strong property rights and other negative rights, increases prosperity and general well-being; and those who used human rights to oppose economic reforms. ${ }^{8}$

6. Engaging thoroughly with all these different positions is beyond the scope of a single article. The angle I wish to take here is narrower but, I believe, also quite unrepresented in the aforementioned discussions. The contribution I aim to make is to shed light on how the increasingly popular humanity discourse (partly encompassing the more specific human rights discourse) in international law is involved in shaping and disciplining the state, and how it is therefore constantly in danger of contributing to the neoliberal project. In making this argument, I draw inspiration from Anne Orford's recent work regarding a "battle for the state" within and through international law. ${ }^{9}$

7. The notion of "battle for the state" and its connection to neoliberalism is

ibid., 23

ibid., Chapter 4.

9 Anne Orford, Food Security, Free Trade, and the Battle for the State, 11 Journal of International Law \& International Relations (2015); Anne Orford, Theorizing Free Trade, in Anne Orford and Florian Hoffmann (eds), The 
introduced in Section II. The following two Sections then seek to prove the main argument of the article, namely that humanity discourse contributes to this "battle for the state", and consequently to the neoliberal project. Section III focuses on humanity discourse in academic theoretical discussion, whereas Section IV concentrates on how humanity language has been used in the practice of global governance. Whilst many of these practical uses of humanity language differ quite drastically from the intentions of the participants in the more theoretical humanity discourse, the theory and practice seem nevertheless to be more or less in line when it comes to their approach to the state. Sections III and IV seek also to shed light on how the disciplining of the state might contribute to the neoliberal project. Section V focuses on the implications of the observations made in the previous Sections. More precisely, it puts forward three interlinked reasons why we should be cautious when our writing and actions may contribute to the battle for the state. Section VI concludes.

\section{International law, neoliberalism and the state}

8. As mentioned above, Anne Orford has recently argued that, since its birth in the nineteenth century, ${ }^{10}$ at the heart of international law has been what she calls "battle for the state"; that is to say, the struggle over what the state should be like, who or what the state should represent, and who will decide. ${ }^{11}$ This battle for the state has been fought perhaps most prominently with regard to free trade. Working closely with political economists and other proponents of free trade, international lawyers have always been deeply engaged in the discussion about the proper limits of the state and the reconstruction of the state through economic integration.

9. In this battle, the liberal project of transforming states into liberal ones, and thus instituting and maintaining free markets, both domestically and internationally, has always been dominant. More recently, however, the hegemony of (neo)liberalism has become even more total as:

the process of securing the foundations of a liberal market economy through international law using the language of rational choice and efficiency 'has become a joint enterprise,' carried out 'by economists, international lawyers, and rational-choice political scientists' with a particular focus upon informing doctrinal scholarship and institutional design through diagnosing 'substantive problems' and proposing legal

Oxford Handbook of the Theory of International Law (2016).

10 Martti Koskenniemi, The Gentle Civilizer of Nations: The Rise and Fall of International Law, 1870-1960 (2002).

11 Anne Orford, Food Security, above n.9, 67. 
solutions. ${ }^{12}$

10. A particularly significant moment in this development has been the establishment of the WTO. As Orford writes, in the WTO era the neoliberal way of thinking has become so embedded within the doctrines and practice of international law that the battle for the state has become almost invisible, as the hegemony of the language of non-discrimination and the removal of barriers to trade has hidden "the relation of trade law to remaking the state". With lawyers and politicians using this language routinely in the everyday practice of trade law and economic governance, its political significance becomes unremarkable, "as if it were no big thing that more and more political decision-making is moved outside the capacity of organised democratic processes." 13

11. If neoliberalism has emerged victorious in the battle for the state, then, it is worth saying a few words on its vision of the economy, the state, and the international order, as well as on its relationship with international law. Neoliberalism is a politico-economic theory which argues that human wellbeing can be best advanced through entrepreneurial freedoms in an institutional setting focused on the facilitation of private property rights, free trade, and free markets. In contrast to classical liberalism, for which the economic sphere is autonomous and spontaneous, neoliberals understand that markets have to be constituted and maintained through interventions. The state therefore plays an important role in neoliberalism, for it is the task of the state to create and preserve the market and the surrounding institutional framework. The state must set up the structures and functions which are necessary for the smooth functioning of markets. At the same time, however, neoliberalism is very suspicious of the state, in particular democracy and mass politics. ${ }^{14}$ As Ntina Tzouvala has demonstrated - focusing especially on the German postSecond World War version of neoliberalism, sometimes referred to as "ordoliberalism" - the neoliberal state has to be a very particular type of state. It must be strong yet limited, using its strength to resist organized interests and guarantee property rights and the uninhibited operation of markets in all possible ways. 15

12. When applied to international law, in the writings of ordo-liberal authors such as Röpke, this kind of thought entails the creation of stable states with limited national sovereignty and a limited range of powers, the abolition of

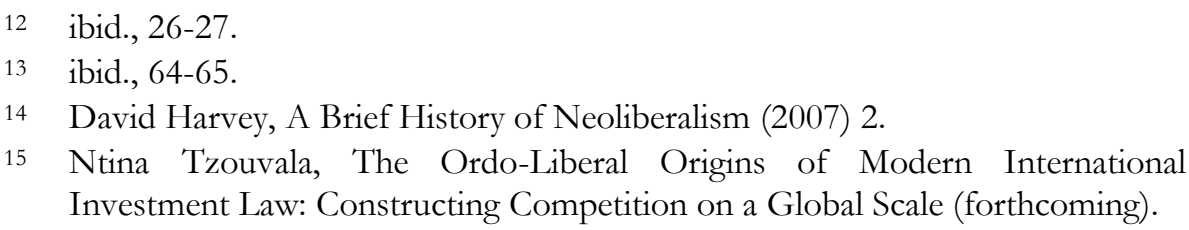


what is seen as "excess sovereignty", and the enhancement of the judiciary at the expense of other branches of government. Furthermore, for the stability of the international order, it is important to extend this model of the state to all corners of the globe. In this way, the argument goes, the abolition of government planning does not lead to anarchy, but is replaced by the order of markets and courts. 16 These ideas have also been shared since their beginnings by the better-known Austrian/Anglo-American strand of neoliberalism, the leading figure of which, Friedrich Hayek, envisioned, too, an international order guided through economic integration. For Hayek, state planning means deliberate discrimination and a threat to rule of law. State planning has therefore to be combated, in particular through economic integration. According to Hayek, the removal of barriers to free movement of goods and capital prevents state planning and "solidarity of interests", and consequently also stops states from developing monetary policy or regulating commercial activity in any way seen as harmful to the neoliberal perspective. Since planning requires common ideas and values, international integration makes such planning much more difficult as decisions will be made through agreements with other societies and cultures. ${ }^{17}$

13. The work of Orford and others on the battle for the state, trade, and investment reveals three important points. First, it opens a new perspective on the history and present of international law as an attempt to discipline and reshape states. Second, it reveals the hegemony of neoliberal rationale in this battle, sometimes concealed behind the routines and language of international law. In other words, it suggests the possibility, or rather danger, that practices which may seem to have nothing to do with neoliberalism or global capitalism might nevertheless contribute to these projects if they help in the process of disciplining the state and relativizing its sovereignty - even if they would do so for purposes very different to market ones. Finally, it hints that the battle for the state is not fought only for the creation of a certain type of international order or to regulate relations between states. Rather, it is fought just as much in order to target markets, institutions, and populations within states. ${ }^{18}$ As Orford argues, against the commonly held view, international law is not only about relations between states. Just as often, it is "about enabling particular kinds of

16 Wilhelm Röpke, International Economic Disintegration (1942), Chapter XXVII; Wilhelm Röpke, Economic Order and International Law, 86 Recueil des cours (1954), 203.

17 Friedrich Hayek, The Economic Conditions of Interstate Federalism (1939), Individualism and Economic Order (1948); The analysis here is from Anne Orford, Theorizing Free Trade, above n.9, 726-727.

18 Anne Orford, Theorizing Free Trade, above n.9, 708. 
administration by one group of people over another, about entrenching particular state forms and not others, about securing particular vital systems of resource exploitation, and about constituting property relations." In so doing, international law is equally interested in internal and external aspects of government. Hence, the state is very much at the center of international law, not always as an actor, but often rather as the target of measures aimed at rooting "particular forms of the state." 19

\section{Humanity discourse in theory}

14. The main argument of this article is that the humanity discourse is one of the practices and discourses which, in producing knowledge of international law, contributes to the battle for the state and - almost certainly against the aims and hopes of most of its proponents - supports the neoliberal project. In what follows, I seek to prove this claim. The present section focuses on how the state is regarded in theoretical humanity discourse. The next section then focuses on how the language of humanity has been used in practice, often with quite different intentions than when used in theoretical discussion. Nevertheless, I suggest that both uses contribute to the battle for the state. Furthermore, the study of the use of the humanity language in practice shows how many of these uses have been intertwined with neoliberal policies.

15. Whilst the humanity discourse takes many forms, it is held together by a few key theoretical ideas. The first of these is obviously the emphasis put on the human. As the argument goes, the human person should be the primary subject of international law; not only a beneficiary, or even $a$ subject, as she is now. As one proponent of law of humanity declares, "[t]he global order rests on the human being, specifically on the unique dignity of the individual and collective human person, the true spring of liberty and equality among all human beings." 20 Similarly, considerations of humanity should not only play an important part in the interpretation of international law; humanity should be the leitmotif of and primary source of legitimacy in international law. ${ }^{21}$ The second key element in the humanity discourse is the conviction that there are certain universal human rights and needs which should be protected always and everywhere - through humanitarian interventions and transformative occupations, many would argue, if need be. It is, however, the third and final theme of the discourse which is most interesting here. ${ }^{22}$ This theme - which is

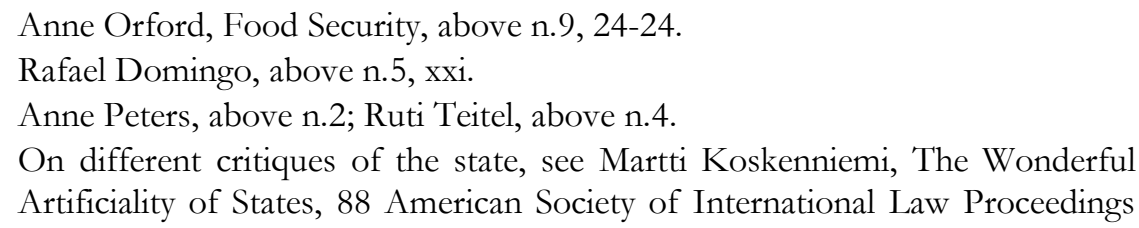


a kind of by-product of the other two - is a certain suspicion of the state. Reasons for the suspicion vary. Some point to the fact that states have traditionally been the main violators of human rights. Others worry that states are becoming incapable of effectively protecting the human rights of their citizens in the condition of increasing globalization. ${ }^{23}$ Others still take a more theoretical stance, and argue that our fixation on the state hinders the progress of international law and its development towards a global law of humanity. ${ }^{24}$

16. Often connected with the suspicion of the state is the managerial mindset, according to which the most fundamental issues touching human life are now increasingly global "and therefore ought to be managed by global networks of knowledge and expertise and outside the anachronistic structures of sovereign statehood." ${ }_{25}$ Conversely, state sovereignty tends to be seen in this mindset predominantly "through its dark side - as a functionally inept and morally corrupt form of absolutism that is used only by domestic elites in order to hide from well-founded international criticism." ${ }^{26}$ Against sovereignty, then, this mindset seems to prefer the authority of technical experts who aim to "manage global problems so as to attain optimally effective solutions." 27 As Martti Koskenniemi explains, the guiding principle seems to be that sovereignty "should not stand in the way of producing 'democracy' or 'rule of law' or 'human rights' or 'security"'. ${ }^{8}$ Consequently, authority is seen to derive from the outcomes of rule: power should be in the hands of those who can de facto protect human life and human rights most efficiently - in contrast to those to whom it may have been given through formal procedures. ${ }^{29}$

17. This mindset is indeed reflected in writings of many participants to the

(1994), 22.

23 Eyal Benvenisti, above n.5, 295 .

24 Rafael Domingo, above n.3, 58; Christopher Barbara, International Legal Personality: Panacea or Pandemonium? Theorizing About the Individual and the State in the Era of Globalization, 12 Austrian Review of International and European Law (2007), 45-47.

25 Martti Koskenniemi, Conclusion: Vocabularies of Sovreignty - Powers of a Paradox, in Hent Kalmo and Quentin Skinner (eds), Sovereignty in Fragments: The Past, Present And Future Of A Contested Concept (2014), 239.

26 ibid.

27 ibid.

28 ibid.

29 See also Anne Orford, Book Review Article: International Territorial Administration and the Management of Decolonization, 59 International \& Comparative Law Quarterly (2010), 246-249; Alexander Somek, The Cosmopolitan Constitution (2014), 233-234. 
humanity discourse. According to Anne Peters, for example, state sovereignty has to be relativized in the sense that it is conditional on effective protection of human rights and human life. ${ }^{30}$ Similarly, according to Jeremy Waldron, states should not be bearers of autonomous value, for they exist only for the sake of human beings, whose well-being is the end of international law. ${ }^{31}$ Accordingly, the state should not be considered so much a subject of international law as an "official" of it. ${ }^{32}$ For Eyal Benvenisti, states should be perceived as "trustees of humanity". Benvenisti notes that we are increasingly confronted with issues which go beyond the jurisdiction of any single sovereign. In a world of increased interdependency and interconnections, the concept of sovereignty should therefore be adapted to the realities of our world in the sense that states should, as trustees of humanity, be bound to take certain other-regarding considerations of humanity into account, even if they are not bound by specific treaties or custom. ${ }^{33}$ Finally, Evan J. Criddle and Evan Fox-Decent have recently introduced the idea of sovereigns as "fiduciaries of humanity". As Criddle and Fox-Decent write, "the time has come to retire the traditional, but increasingly embattled, conception of state sovereignty as exclusive jurisdiction". State sovereignty is therefore not a prerogative of the state but emanates from "a fiduciary relationship between states and the people subject to their jurisdiction". In practice, this means that a state's sovereignty and autonomy "is derived from, and wholly dependent upon", the fulfillment of its fiduciary duties. ${ }^{34}$

18. Whilst the aforementioned authors are unlikely to think in such terms, it is difficult not to see some affinity between their writing and the rationalities which Michel Foucault described as "biopolitics", referring to different technologies and rationales aimed at the maximization of life. ${ }^{35}$ It is important to mention Foucault here because of the connection his work makes between the rationale of protecting life and the very same economic rationale discussed in the previous section of this article. Indeed, in his lecture series titled Birth of

30 Anne Peters, above n.2.

31 Jeremy Waldron, Are Sovereigns Entitled to the Benefit of the International Rule of Law?, 22 European Journal of International Law (2011), 325-326.

32 ibid., 328-330.

33 Eyal Benvenisti, above n.5, 300.

34 Evan J Criddle and Evan Fox-Decent, Fiduciaries of Humanity: How International Law Constitutes Authority (2016), 3.

35 Michel Foucault, The History of Sexuality: The Will to Knowledge: The Will to Knowledge v. 1 (1998); Michel Foucault, Security, Territory, Population: Lectures at the Collège de France, 1977-78 (2007); Michel Foucault, 'Society Must Be Defended': Lectures at the Collège de France, 1975-76 (2003). 
Biopolitics, ${ }^{36}$ Foucault barely mentions the word 'biopolitics' at all, focusing almost entirely on analyzing liberalism and neoliberalism. Biopolitics and (neo)liberalism are, then, clearly linked in Foucault's thinking. A bridge between the two is provided by another one of Foucault's key concepts, namely "governmentality". With that concept, Foucault tried to capture an ensemble of "institutions, procedures, analyses, reflections, and tactics" which allow the exercise of a complex form of power which has "population as its target, political economy as its major form of knowledge, and apparatuses of security as its essential technical instrument." ${ }_{37}$

19. Governmentality is therefore very much the product of (neo)liberal and biopolitical rationales, and a way of realizing both. Indeed, as Anne Orford summarizes the connection between free trade, control of populations, and security:

While debates about free trade and investment often have an abstract and rationally persuasive quality to them, the schemes they propose are dependent upon controlling people and territory. The question of what to do with 'surplus', 'redundant', or displaced populations is a question that has haunted attempts to constitute a market-oriented agricultural order since the nineteenth century. 38

20. Furthermore, the notion of governmentality is important here because it does not perceive states as somehow natural self-evident entities, but rather as ensembles of myriad, sometimes contradictory, rationales and techniques of how to govern. In other words, it tends to lead to similar consequences as described in the previous section in the context of neoliberalism: states are transformed from sovereign actors in pursuit of commonly agreed projects to ensembles of ways of governing, fulfilling managerial aims as efficiently as possible, without democratic support if need be.

21. At this point it should be emphasized, however, that I do not want to argue that the participants in the humanity discourse - or the free trade advocates, for that matter - would aim to get rid of the state altogether. Even the author who is perhaps most critical towards the state within the discourse, namely Rafael Domingo, still sees a role for the state, even if it would be reduced to one institution among many in his "new global law". ${ }^{39}$ Indeed, the aim of both the humanity and the free trade perspective seems rather to be to reduce the role of

36 Michel Foucault, The Birth of Biopolitics: Lectures at the Collège de France, 1978-1979 (2010).

37 Michel Foucault, Security, Territory, Population, above n.35, 108

38 Anne Orford, Theorizing Free Trade, above n.9, 735.

39 Rafael Domingo, above n.5. 
the state and "unbundle" its sovereignty, ${ }^{40}$ exposing it to (usually competing) global rationales which it should start executing in its domestic policies. I therefore want to steer away from drawing any sort of analogy between world politics and the sort of biopolitics which goes on within advanced liberal states, and especially from the idea that the world would be governed by any single logic of rule. But what I do want to emphasize is that different global rationales require the state for their execution and realization. States are what make any sort of implementation of global rationales even remotely possible - but only if they are removed of any sort of "excess sovereignty" which would allow domestic collective planning to oppose those rationales.

22. Thus whilst the discourses of humanity and free trade have somewhat different foci, they seem to be connected in their attempt to reshape the state. Many participants in the humanity discourse seem to believe that global problems dealing with humans across the world would be best managed by international institutions and expert bodies, rather than states, whereas free trade advocates dread any sort of state interventions on markets. Furthermore, the two discourses are connected theoretically in Foucault's work through his notion of governmentality which utilizes the economic rationale in order to secure and maximize the life of the population.

23. So far the analysis of the humanity discourse has remained very theoretical. As such it is open to the Marxian and realist critiques of Foucauldian approaches, according to which the latter tends to lose touch with the actual power dynamics of world politics and international law. In order to escape this critique, then, and to provide some depth and nuance to my argument, I will next analyze how humanity language has been used in practice - often in ways not anticipated by participants in the discourse - and how these uses relate to the free trade project.

\section{Humanity discourse in practice}

24. It is not only within academic quarters that humanity discourse circulates. Instead, humanity language has been transformed into practice through several international operations and within different regimes, often in ways which likely differ quite dramatically from the intentions of the theorists discussed above. My argument in this section is that when the humanity language has been used in practice in this way from the 1990s onwards, it has tended to target states more than individuals or peoples. Or, perhaps more accurately, it has been used to discipline states, perhaps in the process of seeking to improve the lives of

40 See Robert O Keohane, Political Authority after Intervention: Gradations in Sovereignty, in JL Holzgrefe and Robert O Keohane (eds), Humanitarian Intervention: Ethical, Legal and Political Dilemmas (2003). 
individuals. Furthermore, some of the operations harnessing the humanity language have been entangled with neoliberal policies. Methodologically, my intention in this section is to "go wide" in order to paint a larger picture. This means that I cannot provide detailed "case studies"; rather, my contribution is to draw together and combine the results of more detailed studies done by others.

25. The final breakthrough of human rights gave a huge boost to the dissemination of the humanity discourse in the early 1990s. Nevertheless, the discourse had perhaps its largest impact during the UN's territorial administration missions. Relying heavily on humanity rhetoric, the UN took effective control of Bosnia-Herzegovina in 1995, Eastern Slavonia in 1996, and Kosovo and East Timor in 1999. While international territorial administration is an old and established practice, ${ }^{41}$ some commentators have seen these missions as the beginning of a radically new version of it, dubbed "humanitarian occupation". ${ }^{42}$ Unlike in previous cases, such as the trusteeship system, the welfare of the population and the protection of human rights and human life are now, according to Fox, "genuinely" the primary concern of the occupiers. Furthermore, according to Stahn, the missions fed the rethinking of sovereignty and challenged the state-centered vision of territorial authority and governance, supporting the claim that international law is increasingly about organizing individual and people's rights. ${ }^{43}$

26. The outcomes of the humanitarian occupation missions were massive. ${ }^{44}$ As Stahn writes, "international actors took it on themselves to organize societies in a manner that purports to promote the functioning of domestic institutions and the realization of the rights of individuals." Human rights were used to justify large-scale reforms to state institutions, even completely rebuilding the state if necessary. ${ }^{45}$ In the words of Fox, humanitarian occupation missions are best seen as social engineering projects aimed to reform governmental institutions for the benefit of the life of the administered population in a context where protection of humanity has become "a question for the broader international

41 Ralph Wilde, International Territorial Administration: How Trusteeship and the Civilizing Mission Never Went Away (2010), passim.

42 Gregory H. Fox, Humanitarian Occupation (2008).

43 Carsten Stahn, The Law and Practice of International Territorial Administration: Versailles to Iraq and Beyond (2010), 755-756.

44 See Anne Orford, Reading Humanitarian Intervention: Human Rights and the Use of Force in International Law (2007), Chapter 4; Anne Orford, Book Review Article, above n.29.

45 Carsten Stahn, above n.43, 755-756. 
community." ${ }_{46}$ Wilde has made a particularly interesting point in this regard, writing that international territorial administration projects have not in fact so much responded to the consequences of a conflict, as commonly assumed, but rather patched vacuums created by the missions themselves. In other words, rather than operating reactively to bridge existing gaps, UN authorized administrators have operated actively, displacing local actors in order to create different policy changes. ${ }^{47}$

27. In particular, international actors sought to transform the administered territories into distinctly (neo)liberal states. ${ }^{48}$ As Korhonen, Gras, and Creutz write

One of the inherent characteristics in post-conflict governance from the 1990s onwards has been the normative agenda of liberalism pursued by international administrations [...] It includes e.g. the holding of multi-party elections, constitutionalism, the rule of law, the human and minority rights, good governance, and economic liberalization. ${ }^{49}$

This "liberal peacebuilding package" was, Korhonen, Gras, and Creutz continue, pursued in all post-conflict situations as if it were neutral and universally accepted ${ }^{50}$ - the peacebuilders never stopped to ask whether the package fit the target country, but the success of all the projects was measured simply in terms of certain liberal yardsticks, such as the holding of elections and the establishing of key institutions. ${ }^{51}$

28. Fox paints a similar picture. In Bosnia, for example, wide implementation responsibilities were assigned to the UN, UNHCR, ICRC, NATO, OSCE, and the World Bank. The ECHR was made to apply directly and have propriety over all other law. Civilian authority was put in the hands of the "international community", represented through the Office of the High Representative, which was granted jurisdiction "over virtually every aspect of economic reconstruction, human rights and institutional rehabilitation", as well as the authority to interpret the Dayton documents. ${ }^{52}$ Similarly, in Kosovo all legislative and executive powers were vested in the UN Mission in Kosovo (UNMIK). Civilian administration was to be controlled by the UN, humanitarian affairs by the UNHCR, institution building by the OSCE and

46 Gregory H. Fox, above n. 42, 72.

47 Ralph Wilde, above n.41, 233.

48 Anne Ordord, Book Review Article, above n.29.

49 Outi Korhonen, Jutta Gras and Katja Creutz, International Post-Conflict Situations: New Challenges for Co-Operative Governance (2006), 37-38.

$50 \quad$ See also Anne Ordord, Book Review Article, above n.29, 243.

51 Korhonen, Gras and Creutz, above n.49, 37-38.

52 Gregory H. Fox, above n.42, 81. 
reconstruction by the EU. Moreover, the Security Council ordered UNMIK to establish institutions for multi-ethnic government, the application of international human rights instruments, democratic governance, and a marketbased economy, ${ }^{53}$ and the interim administration has indeed made full use these powers. ${ }^{54}$

29. In East Timor, the UN Transitional Administration in East Timor (UNTAET) was established to take overall responsibility for the administration of East Timor and to exercise all legislative and executive authority, leading quickly into controversies with the local population which found UNTAET to be very unreceptive to any of their wishes and complained repeatedly of autocratic rule - most importantly when UNTAET entered into a treaty with the World Bank on a local governance project on behalf of East Timor. The World Bank took control of the economic governance of the country, aiming to transform the society's "culture of subsistence and informal economy" into "one that develops capitalism, creates opportunity and ultimately formalizes the economy." 55 Furthermore, the World Bank reformed East Timor's agriculture radically, guided by the Bank's long-established vision that agriculture should be a commercial activity included into global value chains - even with the possible detriment to local food security and food sovereignty - leading to disastrous effects following the global food crisis of 2008.56

30. The world has changed quite radically since the beginning of the humanitarian occupation missions and it is therefore very unlikely that we will witness more such missions, at least in the near future. A kind of swan song of the practice was the occupation of Iraq in 2003. Unlike the humanitarian occupation missions, it did not gain the acceptance of the international community, conducted instead by the United States and its allies unilaterally. Nevertheless, much like the humanitarian occupation missions, the occupation of Iraq, too, was justified with humanity rhetoric. There was hardly a single press release during the Iraq mission which did not refer to the human rights of the Iraqi people, but the more legal link between human rights and social transformation was spelled out perhaps most clearly in the testimony of former U.S. Deputy Assistant Attorney General in the Office of Legal Council John Yoo to a Senate hearing regarding human rights, constitutionalism, and the rule

53 Security Council Resolution 1244 (June 10, 1999).

54 Gregory H. Fox, above n.42, 95.

55 Oliver P. Richmond and Jason Franks, Liberal Peacebuilding in Timor Leste: The Emperor's New Clothes? 15 International Peacekeeping (2008), 197.

56 Ntina Tzouvala, 'Food for the Global Market: The Neoliberal Reconstruction of Agriculture in Occupied Iraq (2003-2004) and the Role of International Law' (2017) 17 Global Jurist. 
of law in Iraq. ${ }^{57}$ In his testimony Yoo fiercely defended an expansive reading of the law of occupation, arguing that a broad discretion to reform the occupied state is necessary to ensure the protection of human rights and democracy. ${ }^{58}$ Hence, "it almost certainly will be necessary for the United States to change Iraqi law to dismantle current Iraqi government institutions and create new ones to take their place." 59

31. The measures taken by the occupiers were extensive indeed. The Coalition Provisional Authority (CPA), established to administer Iraq for the duration of the occupation, asserted at the outset that the goals of the interim administration were to introduce wide-ranging reforms in Iraq. All CPA regulations and orders spelled out the legal basis for the legislation and routinely invoked the well-being of the Iraqi people.60 Iraq's Penal Code was amended several times in the name of international human rights law. ${ }^{61} \mathrm{~A}$ Central Criminal Court was established in the name of the Iraqi population and a Special Tribunal in the name of public order and international rule of law. ${ }^{62} \mathrm{~A}$ Human Rights Ministry was set up and the minimum age of work changed in order to protect health, safety, and morals of children. ${ }^{63}$ Vast economic reforms included changes to trade law, company law, securities law, bankruptcy law, intellectual property law, and copyright law, as well as the introduction of flat tax rates. The result was perhaps the world's most investor friendly legislation, as well as a drastic shrinking of the public sector. Moreover, Ntina Tzouvala has demonstrated how Iraq's farming was reconfigured along neoliberal, corporate lines and absorbed into global food chains with massive impacts for the local population. ${ }^{64}$ The CAP justified these changes by stating that it worked closely with the Governing Council and in co-operation with international financial institutions in order to fulfil its responsibilities toward the Iraqi people, aiming to improve conditions of life. ${ }^{65} \mathrm{All}$ in all, the CPA transformed Iraq "from a centralized dictatorship into a market-based democracy" by completely re-programming the Iraqi legal, political, and

57 John Yoo, Iraqi Reconstruction and the Law of Occupation (2004) 11 U.C. Davis JILP (2004).

ibid., 21.

ibid., 22.

Eyal Benvenisti, The International Law of Occupation (2012), 257-259.

ibid., 260.

ibid., 261.

ibid., 260-261.

Ntina Tzouvala, above n.56.

Eyal Benvenisti, above n.60, 262-263 
economic system. 66

32. Even if humanitarian occupations or even such unilateral occupations as in the case of Iraq are unlikely to repeat in the current political context, where the United States has lost its position as an unchallenged superpower, some of the elements behind the use of the humanity language in those missions have lived on in a different guise. Whilst the responsibility to protect and human security discourses have moved away from direct forms of intervention, dominant in the 2001 ICISS Report, its focus on liberal state-building has amplified. This is reflected, for example, in the 2009 document Implementing the Responsibility to Protect, which concentrates on building the capacity of states to fulfill their responsibility to protect. According to the Report, the main threat to human security is "the weak institutional capacity of some sovereign states", rather than "the legal barrier of sovereignty itself." ${ }^{67}$ Similarly, when the General Assembly finally came to a common understanding on human security in 2012, it defined human security as "an approach to assist Member States in identifying and addressing widespread and cross-cutting challenges to the survival, livelihood and dignity of their people." 68 Whilst the actual content of the Resolution remained rather vague, ${ }^{69}$ the definition clearly highlights the importance of the state for human security: human security is to be achieved by building states and their capacities, and must be implemented with respect to territorial integrity. ${ }^{70}$

33. This is reflected also in "post-developmentalism" in the Third World more generally. As outlined, for example, in the World Bank's 2011 World Development Report, Conflict, Security and Development, post-developmental policies distinguish between stable and fragile states based on their ability to respond to different forms of stress. Fragile states are at the center of postdevelopmentalism because their vulnerability to different outbreaks threaten the ability of economy to "sustain increases in per capita income over the long term", and therefore jeopardize economic growth more generally - not only in the Third World, but also globally.71

34. Yet it might be that we are already moving beyond responsibility to protect

66 ibid., 268.

67 David Chandler, Understanding the Gap between the Promise and Reality of the Responsibility to Protect, in Philip Cunliffe (ed), Critical Perspectives on the Responsibility to Protect: Interrogating Theory and Practice (2012) 26-27.

68 GA Res 66/290, Follow-up to Paragraph 143 on Human Security of the 2005 World Summit Outcome', UN Doc A/Res/66/290, Supp 14, 117, para. 3.

69 Martin Wählisch, Human Security: Concept and Evolution in the United Nations, 18 Max Planck Yearbook of United Nations Law Online (2014), 17 19.

70 GA Res 66/290, above n.68, para. 3, provisions d-h.

71 Hani Sayed, The Humanization of the Third World (forthcoming). 
as well. Today, the impact of the humanity language is perhaps largest in regards to counter-terrorism and the refugee question. In counter-terrorism, humanity language has played an important role in changing the position of the UN Security Council "from a political executive body established by treaty to enforce the peace and provide collective security in a crisis, to the executive organ of the international community, enforcing its global constitutional law". ${ }^{72}$ 35. The United States and its allies took advantage of the new possibilities of the Council in the war on terrorism by using the Council to "legislate", 73 producing what some have called "global security law" and extending its cover across the world. ${ }^{74}$ Humanity language was used both to facilitate this process and to resist it. Many used the human rights language to draw attention to the atrocities committed in the name of counter-terrorism, ${ }^{75}$ but the United States and its allies also learned quickly to use the language for their benefit.

36. Not only was the war on terror often presented as necessary for the protection of the human rights to life and security, ${ }^{76}$ but superficial human rights rhetoric, as well as the language of "international community", were also quickly woven into the operation of the Counter-terrorism Committee in order to assure troubled states and ensure their cooperation. ${ }^{77}$ This allowed the production of "a concerted, coordinated anti-terrorism campaign that has united most countries in the world in a common template of action." 78 States were swiftly convinced to develop domestic policies which were remarkably

72 Jean L Cohen, Globalization and Sovereignty: Rethinking Legality, Legitimacy, and Constitutionalism (2012), 270.

73 Paul Szasz, The Security Council Starts Legislating, 96 American JIL (2002); José Alvarez, Hegemonic International Law Revisited, 97 American JIL (2003); Stefan Talmon, The Security Council as World Legislature, 99 American JIL (2005); Kim Lane Scheppele, Empire of Security and the Security of Empire, 27 Temple ICLR (2013), 259.

74 Kim Lane Scheppele, above n.73.

75 See especially the several reports by the UN Special Rapporteur in the Promotion and Protection of Human Rights and Fundamental Freedoms while Countering Terrorism, Martin Scheinin. See also Rosemary Foot, The United Nations, Counter Terrorism, and Human Rights: Institutional Adaptation and Embedded Ideas, 29 Human Rights Quarterly (2007); Paul Hoffman, Human Rights and Terrorism, 26 Human Rights Quarterly (2004); Joan Fitzpatrick, Speaking Law to Power: The War Against Terrorism and Human Rights, 14 European JIL (2003).

76 Paul Hoffman, above n.75, 99.

77 Kim Lane Scheppele, above n.73 248-249; Rosemary Foot, above n. 75, 511512. See also Martti Koskenniemi, International Law and Hegemony: A Reconfiguration, 17 Cambridge Review of International Affairs (2004), 200.

78 Kim Lane Scheppele, above n.73, 249. 
similar, allowing the core, most importantly the United States, to control what goes on in "the periphery", and thus "discipline populations both in the center and the periphery while appearing to shape only the latter." 79 As Kim Lane Scheppele comments, "the new global security law operates primarily by permitting strong states to shape the content of the internal legal systems of weak states, which facilitates the peripheral regimes doing the jobs they have been delegated." 80

37. The refugee protection system, again, has slowly developed from a simple treaty regime to a complex network of humanitarian governance. With humanitarian governance I mean, following Michael Barnett, "the increasingly organized and internationalized attempt to save the lives, enhance the welfare, and reduce the suffering of the world's most vulnerable populations." 81 Refugee protection is now at the heart of this attempt, the refugee crisis lying "at the intersection of multiple regimes," and being governed through different fields of law, including but not limited to refugee law, human rights law, and international humanitarian law. 82

38. As Agier writes, the humanitarian governance of refugees is "a globalized apparatus: a set of organizations, networks, agents, and financial means distributed across different countries and crisscrossing the world". ${ }^{83}$ It protects life, but also enables the smooth functioning of global life by regulating movements of displaced populations and clearing up the "confusion" caused by individuals ending up beyond their national borders. As Francois Debrix notes, the "UNHCR gathers individual subjects, redistributes them, and finally provides them with a new internationally recognizable identity". ${ }^{84}$ The dark side of this process is, according to some critics, that the rigorous selection process of refugees in the Global North is enabled by camps in the South. ${ }^{85}$ In a way, the refugee system provides one solution to the old question of what to do

79 ibid., 251

80 ibid., 277.

81 Michael N Barnett, Humanitarian Governance, 16 Annual Review of Political Science (2013), 279.

82 E Tendayi Achiume, 'Syria, Cost-Sharing, and the Responsibility to Protect Refugees' (2015) 100 Minnesota Law Review 687, 711.

83 Michel Agier, Humanity as an Identity and Its Political Effects (A Note on Camps and Humanitarian Government), 1 Humanity: An International Journal of Human Rights, Humanitarianism, and Development (2010), 32.

84 François Debrix, Space Quest: Surveillance, Governance, and the Panoptic Eye of the United Nations, 24 Alternatives: Global, Local, Political (1999), 287-288.

85 Didier Fassin, Policing Borders, Producing Boundaries. The Governmentality of Immigration in Dark Times, 40 Annual Review of Anthropology (2011), 216-217. 
with the world's "surplus population". ${ }^{86}$ Humanitarian governance normalizes the refugees in the sense that they are no longer "free-flowing, wandering, or nomadic individuals", but are "reorganized and reinserted within the international community as yet another type of calculated distribution." ${ }_{87}$

39. To answer the question of what has been done with the humanity language within the aforementioned regimes, then, my argument is that the measures taken have had more to do with disciplining states than reaching individuals and peoples directly. All of these actions are said to have been conducted for the benefit of humanity or some more specific groups of humans, yet the results in this respect have been somewhat mixed. There is no doubt that at least some of the operations and practices have brought great humanitarian relief. Nevertheless, the new focus on the human seems to mean primarily "the prevention of cruelty and the preservation of bare human life against persecution and atrocities perpetrated by either governments or social groups. 88 It is therefore mostly about what Didier Fassin has called "biolegitimacy", that is to say, the recognition of life - understood in the sense of simply being alive - as the most fundamental of all values. ${ }^{89}$ This kind of protection of life is certainly a crucially important goal; yet it should be pointed out that it does not necessarily lead to the empowerment of human beings. Moreover, when applied in practice it tends to require distinctions to be made between lives to be saved, lives to be risked, and lives to be sacrificed. ${ }^{90}$ This is reflected in a compact form in refugee camps in which refugees are in practice "divided into several distinct subcategories of "vulnerability", and to "good" and "bad" refugees. ${ }^{91}$

40. Where the outcomes have been more consistent and more in line with humanity rhetoric, however, is with regard to states. In all of the examples mentioned above, humanity rhetoric has been used to limit and reconceptualize state sovereignty or change domestic legislation and institutions. Whilst the humanitarian occupation missions are an extreme example and are unlikely to repeat in the near future, and it might be that we are moving beyond

86 See further Mark Duffield, Human Security: Linking Security and Development in an Age of Terror, in Stephan Klingebiel (ed.), New interfaces between security and development: Changing concepts and approaches (2006).

87 François Debrix, above n.84, 287-288.

88 Alexander Somek, above n.29, 153-154.

89 Didier Fassin, Humanitarian Reason: A Moral History of the Present (2011), 249. See further Didier Fassin, Another Politics of Life Is Possible, 26 Theory, Culture \& Society (2009); Didier Fassin, Compassion and Repression: The Moral Economy of Immigration Policies in France, 20 Cultural Anthropology (2005).

90 Didier Fassin, Humanitarian Reason, above n.89.

91 Michel Agier, above n.83 39. See also Dider Fassin, above n.85. 
responsibility to protect as well, the attempt to discipline the state is visible also in post-developmentalism. ${ }^{22}$ Furthermore, the counter-terrorism campaign has been very efficient in convincing states into adopting almost uniform, rather deep-reaching legislation in the protection of human security. Outside the regimes mentioned above, several measures in international criminal law have attempted to "disrupt the relationship between the individual and the State and relegate the latter from its status as the primary actor in the international system", ${ }^{3}$ thus increasing the power of international tribunals which are seen as "the engine of an expanding global rule of law". ${ }^{94}$ From this perspective, then, state action starts to seem "more like a dilution of an international tribunal than a necessary and beneficial complement to it". ${ }^{95}$ Within international human rights law, a very notable recent development is the increasing use and relevance of indicators and periodic reviews. Indicators - which, importantly, depend on political decisions on what qualifies as worth measuring and what is left outside - shape national governmental decision-making, as it is important for many states to perform well in light of the indicators in order to boost their reputation and have access to resources. ${ }^{96}$ Similarly, the Universal Periodic Review - treating states as isolated entities, removed from any historical, political, or economic context and their relations with other states and non-state actors, and measuring their performance according to certain "universal" standards ${ }^{97}$ - tends to push "at the boundary of non-interference" in its recommendations by fellow states and in its pressure to adopt certain practices, institutional structures, and standards. ${ }^{98}$

41. Nevertheless, it should be emphasized that the humanity project has not been used against the state per se. That is to say, it has not challenged the existence and territorial integrity of states. Indeed, while the rhetoric of humanity has been used to shape and perhaps even hollow the state, at the

92 Hani Sayed, above n.71.

93 Padraig McAuliffe, From Watchdog to Workhorse: Explaining the Emergence of the ICC's Burden-Sharing Policy as an Example of Creeping Cosmopolitanism, 13 Chinese JIL (2014), 268.

94 Tor Krever, International Criminal Law: An Ideology Critique, 26 Leiden JIL (2013), 702.

95 McAuliffe (n 95) 269.

96 Kevin Davis, Benedict Kingsbury and Sally Engle Merry, 'Indicators as a Technology of Global Governance, 46 Law \& Society Review (2012), 83-84.

97 Jane Cowan and Julie Billaud, Between Learning and Schooling: The Politics of Human Rights Monitoring at the Universal Periodic Review, 36 Third World Quarterly (2015), 1179.

98 ibid., 1181. 
same time the shell of the state has been maintained meticulously. In other words, while the practices described above may have challenged state sovereignty as traditionally understood, as well as the right to selfdetermination, they seem at the same time to support the continued existence of states, and an international order built around states. This was reflected even in the extreme example of humanitarian occupation missions. According to Fox, the fact that the Security Council took the exceptional measures of humanitarian occupation "suggests a deep commitment to preserving existing states, but equally to a model of the state as embodied in the human rights and territorial integrity norms". In all cases of humanitarian occupation, existing borders were preserved and populations maintained intact and in particular places - sometimes even with the help of coercive measures. ${ }^{99}$ According to Wilde, then, international territorial administration bolsters "the norm that the global political space should be divided into Westphalian states". ${ }^{100}$

42. Furthermore, whilst some have argued that humanitarian governance of refugees entails the emergence of de-territorialized politics, the practice of refugee protection seems to lead in the completely opposite direction, the regime effectively maintaining an international order of states where "the human population is segmented, ordered, and governed". Hence, even though refugee protection is a global regime, governed by a fluid network built mostly by nongovernmental actors, it by no means challenges the importance of the state in global law and politics, nor does it bring about the demise of the state. Rather, it redistributes authority from states to the international community, whilst at the same time highlighting the centrality of the order of states. 101 Similarly, while human rights have allowed deep-reaching interventions into core areas of states, the human rights system is based completely on the relation between states and their citizens. As Patrick Macklem writes, the role of human rights law is to monitor and control the exercise of state sovereignty, but at the same time relies on a system built around states. Human rights are therefore not so much a product of moral insight as a counterbalance to "the adverse effects of how we organize global politics into an international legal order." ${ }^{102}$ Even the counter-terrorism campaign used states, acting through

\footnotetext{
99 Gregory H. Fox, above n.42, 73

100 Ralph Wilde, above n.47, 256.

101 Robyn Lui, The International Government of Refugees, in Wendy Larner and William Walters (eds), Global Governmentality: Governing International Spaces (2004), 121.

102 Patrick Macklem, The Sovereignty of Human Rights (2015), 2.
} 
them by swiftly producing a global anti-terrorism network. ${ }^{103}$

43. To sum up, this section has argued that when humanity language has been put into practice, its most direct results have had perhaps less to do with individuals and peoples than with disciplining the state. Whilst none of the practices challenge the existence and territorial integrity of states, and seem to uphold the notion of an international community built around states, they have nevertheless used humanity language to intervene within domestic matters, shape states into a certain liberal form, and/or limit their sovereignty and possibilities to engage in collective domestic projects and state-planning. In this sense, the practice seems to differ from the way humanity language is used in theory when it comes to the human, but aligns with it in regards to the state, which is treated as a fiduciary, trustee, or official of humanity by many authors. This section has also given a few examples of how humanity discourse and neoliberal policies have been connected in practice. Most of the humanitarian occupation missions involved the complete neoliberalization of the political institutions and economic system of the target states, and in Iraq human rights language was used to justify an even more radical transformation of the society into a neoliberal market-based one. Furthermore, human rights and neoliberal policies are enmeshed also in the World Bank's lending practices and developmental policies.

\section{Implications: in defense of the state}

44. The argument put forward in the previous two sections has been that whilst there are great differences between the theoretical human rights discourse and the way the humanity rhetoric is used practice, what they have in common is an attempt to discipline the state. In this way, I have argued, the participants in the humanity discourse have contributed - perhaps unwillingly - in the "battle for the state" that Anne Orford has shown to characterize international law for a long time, in particular in relation to free trade. This section focuses on the implications of that argument. In other words, it seeks to show why we - the participants in the humanity discourse - should be wary about this development.

45. For me, there are three reasons for finding the connection between the humanity discourse and the battle for the state worrisome. The first relates to the function of state sovereignty. For many participants in the humanity discourse, state sovereignty seems to signify an excuse for states to mistreat their population without consequences, or some kind of remnant of nationalism. These dangers should be taken seriously, to be sure. Nevertheless, this tendency to view state sovereignty predominantly through its dark side has

103 Kim Lane Scheppele, above n.73, 276. 
the problem of neglecting the other side of the coin; the bright side of state sovereignty. This bright side has been described by Martti Koskenniemi as enabling "collective life as a project". ${ }^{104}$ In contrast to many participants in the humanity discourse, Koskenniemi distinguishes his defense of state sovereignty from any kind of nationalism or idea of natural, organic communities. Indeed, what is to be defended is precisely the "wonderful artificiality of the state". ${ }^{105}$ 46. The state provides "a set of institutions or practices in which the forms of collective life are constantly imagined, debated, criticized and reformed, over and again." The project that Koskenniemi envisions is therefore not one of essence but - by contrast - of becoming. In fact, it is the governance and managerialism preferred by many participants in the humanity discourse which tend to rely on "essences" in assuming that human beings are "born readymade, with stable and unchanging preferences, always acting with a view to maximizing utility". ${ }^{106}$ Moreover, the dispute relating to state sovereignty should not be imagined as one "about who is nationalist' or who 'internationalist'." Instead, it is about different versions of "what domestic democracy and international governance ought to be", and about carving space for such discussion in the first place. ${ }^{107}$

47. The second reason for caution is in a way the flipside of the first one. If the first point was that many participants in the humanity discourse tend to view state sovereignty only through its dark side - as enabling abuse - it could also be argued that they tend to view the increased power of international institutions only through their bright side, forgetting that they, too, can be tools of power and enable abuse. In other words, the humanity discourse underestimates the extent to which globalization has reshaped sovereignty, and in particular the extent to which sovereignty can be an attribute of the global order. As Hardt and Negri have argued, previous dichotomies between rulers and ruled, core and periphery have become blurred, or deterritorialized and reterritorialized, in today's world. ${ }^{108}$ In particular, sovereignty has disseminated to the global level and within states. Instead of clear dichotomies, we have today new types of hierarchies, "constituted and sustained by more complex patterns and logics, which are obscured, and hence reinforced, where globalization is

104 Martti Koskenniemi, Conclusion, above n.25, 241.

105 Martti Koskenniemi, The Wonderful Artificiality of States, above n.22.

106 Martti Koskenniemi, Conclusion, above n.25, 241.

107 Martti Koskenniemi, It's Not the Cases, It's the System, 18 Journal of Investment \& Trade (2017), 351.

108 Michael Hardt and Antonio Negri, Empire (2001). 
elided with neo-imperialism." ${ }^{109}$ Furthermore - both building on and contra Hardt and Negri - power does not have to be in the hands of those with authority. Thus those who are sovereign in the sense that they can exercise authority do not necessarily have to be those who actually wield power behind that veil of authority. Rather, different institutions and networks can serve to veil and legitimize the exercise of power of those actors who get to act through them, as was witnessed in the United States acting through the Security Council and the CTC with regard to the war on terrorism.

48. The third reason for caution is closely interwoven with the first two, in particular with the loss of national defense mechanisms and collective planning, as well as with the new forms of power created in the process of globalization. Together these processes, and the drawing of the state into global markets, culture, and governance, has limited the policy options of the state. What makes this development so worrisome - and this is my third point - is the current hegemony of the neoliberal economic rationale. As the economic rationale has become increasingly disembedded from society and turned global, for example in the form of international trade rules, societies are increasingly viewed as the economy. Consequently, different principles of social organization are separated from each other and ranked accordingly, producing regimes which privilege economic efficiency. This tends to force states to shape themselves into a uniform model with little regard to their particular socioeconomic, political, and historical idiosyncrasies. As Audrey R. Chapman writes, in regards to health policy and the human right to health:

In a globalized system many states, particularly poor ones, have significant constraints on both their ability and their freedom to implement human rights obligations, or, to describe the situation in another way, global market integration is shrinking the ability of all governments to make decisions about health without taking into consideration such factors as economic competitiveness, credit worthiness, debt payments to external creditors, and complying with trade agreement conditions, even when these are contrary to human rights paradigm and impose health negative effects. ${ }^{110}$

Indeed, as Paul O'Connel has argued, this process of "neoliberal globalization" is inimical to the fundamental aims of the humanity discourse - the protection of the human rights and human security of the oppressed, and the

${ }^{109}$ Susan Marks, Empire's Law The Earl A. Snyder Lecture in International Law, 10 Indiana Journal of Global Legal Studies (2003), 463-464.

110 Audrey Chapman, Global Health, Human Rights, and the Challenge of Neoliberal Policies (2017), 20. 
empowerment of the weak. ${ }^{111}$ Whilst neoliberalism relies strongly on some classic, negative rights, most importantly the right to property, it tends to be hostile towards positive rights, reducing its capacity to fulfil its human rights obligations. ${ }^{112}$

49. However, I also wish to add a few caveats to the arguments made in this section. First, separating out the three points above is, of course, quite artificial in the sense that they are tightly interwoven and feed one another. The less the state can engage in collective planning, the more it is exposed to global rationales. And the stronger the pressures of globalization and neoliberalization become, the narrower the leeway of the state becomes. Similarly, globalization and neoliberalism are connected in the sense that globalization disseminates the neoliberal rationale around the world, whereas the neoliberal attitude facilitates globalization by creating free global markets and unifying state policies. Second - and most importantly - I do not want to suggest that neoliberal policies are only forced on states from outside. By contrast, the shift occurs also from within and below, ${ }^{113}$ not least because it tends to grant great benefits for state elites and others who are in the position to take advantage of privatization and international investment. Third, and finally, I want to emphasize that I do not want to view globalization exclusively as a negative phenomenon, nor am I against international institutions or the notion that state sovereignty has to be sometimes pierced for the protection of human rights. Nevertheless, I hope that I have managed to prove that there is reason for caution and careful thinking when our writing and actions might contribute to the battle for the state which is currently so dominated by neoliberal ideas.

\section{Conclusion}

50. Whilst it has recently suffered some backlashes in the form of the rise of populism, xenophobia, and nationalism around the world, humanity discourse has nevertheless risen to a prominent position in international law in the past couple of decades. It is therefore important to subject it to critical scrutiny, in order to understand its potential, but also its blind spots. This article has aimed to contribute to that critique. Since such a task is too great for one journal article, this one has focused only on one aspect of the humanity discourse, namely its relation to the state.

111 Paul O'Connell, On Reconciling Irreconcilables: Neo-Liberal Globalisation and Human Rights, 7 Human Rights Law Review (2007).

112 ibid., 501.

113 See Sahib Singh, The Fundamental Rights of States in Neoliberal Times, 4 Cambridge Journal of International and Comparative Law (2015). 
51. The key argument of the article has been that the increased humanity discourse contributes to what Anne Orford has called the "battle for the state", and has in so doing ended up reinforcing the hegemonic neoliberal project in world politics - most likely contrary to the aims of many participants in the humanity discourse. This argument has been backed up by an analysis of both the academic, theoretical humanity discourse, and the use of its key ideas in practice. The theoretical discussion is linked to the battle for the state especially by its suspicion of the state and its managerial mindset, which bears some resemblance to the rationale which Foucault described as biopolitical governmentality. These abstract theoretical musings were confirmed through analysis of humanity language in practice. Whilst the way humanity language has been transformed into practice - and in particular the outcomes this transformation has produced - differs in many ways from the aims of many academic participants in humanity discourse, it seems to support its main tenets regarding the state. Although the practice seems to have bolstered the existence and territorial integrity of the state, and reaffirmed its continued importance for world politics and global law, it has contributed to the unbundling of state sovereignty and the limiting of state power, and has disciplined states into adopting a certain very specific liberal form.

52. Moreover, the analysis of the theory and practice of humanity discourse highlighted some connections between the discourse and neoliberalism. Theoretically, these links are no doubt often unintentional and are provided especially by the notion of governmentality, which links maximization of the life of the population to the economic rationale. But in practice this connection is much clearer in the way humanity language has been used to justify massive economic transformations, for example as part of humanitarian occupation missions, the occupation of Iraq, and food security measures.

53. I have suggested that the link between humanity discourse and the neoliberally-dominated battle for the state is very troublesome. It removes the possibility of collective, political projects of becoming, as well as possibilities for resistance, and as such not only contributes to "the effort to isolate markets from local political contestation", ${ }^{114}$ but also limits the states' options to fulfil their (positive) human rights obligations and ensure the well-being of their populations. Furthermore, it serves to hide the exercise of power behind the veil of international institutions and fluid global networks and as such

114 Koskenniemi, It's Not the Cases, It's the System, above n.Virhe. Kirjanmerkkiä ei ole määritetty., 346. See generally Karl Polanyi, The Great Transformation: The Political and Economic Origins of Our Time (2002). 
safeguards hierarchy both globally and within states. ${ }^{115}$ Thus, whilst there is much to applaud in the increased circulation of the humanity discourse, both in academia and in practice, we should remain cautious of its potential effects when it becomes entangled with hegemonic global rationales.

115 See further Ntina Tzouvala, above n. 15. 